\title{
Determining the Sr isotopic composition of waterlogged wood - Cleaning more is not always better
}

\author{
A. Van Ham-Meert ${ }^{\text {a,b, }}$, A.S. Rodler ${ }^{\text {a,b,1 }}$, T.E. Waight ${ }^{\mathrm{b}}$, A. Daly ${ }^{\mathrm{a}}$ \\ ${ }^{a}$ Saxo Institute, University of Copenhagen, Karen Blixens Plads 8, DK-2300, Copenhagen, Denmark \\ ${ }^{\mathrm{b}}$ Department of Geosciences and Natural Resource Management (Geology Section), University of Copenhagen, Øster Voldgade 10, DK-1350, Copenhagen, Denmark
}

\section{A R T I C L E I N F O}

\section{Keywords:}

Sr isotopes

Timber

Dendrochronology

Waterlogged

\begin{abstract}
A B S T R A C T
Sr isotopes represent a potential means to trace the provenance of archaeological timber. Such tracing allows us to examine the transport, by past people, of wooden objects and of wood and timber as a raw material. However, issues exist with the mobility of $\mathrm{Sr}$ and addition of exogenous $\mathrm{Sr}$ during waterlogging. This paper presents a systematic assessment of cleaning methods to remove exogeneous Sr from waterlogged wood. Neither a large number of Milli-Q washes, a combination of MQ and Hydrofluoric acid (HF) or alpha-cellulose extraction were able to retrieve the original signature. It was also shown that ashing leads to higher uncertainties due to the smaller amount of Sr available for analysis, this method will only be really useful when large samples are available, is not recommended for small archaeological samples. Our studies also highlight that the distribution of $\mathrm{Sr}$ in waterlogged wood is highly heterogeneous.
\end{abstract}

\section{Introduction}

Strontium (Sr) isotopes have proven to be a potentially powerful tool for geological, biological and archaeological provenancing purposes (Barnett-Johnson et al., 2008; Waight and Tørnqvist 2018; Frei et al., 2019). In archaeological research, applications range from tracing human migration (e.g. Beard and Johnson 2000; Horstwood et al., 2008) to determining the provenance of glass (Brems et al., 2013), ceramics (De Bonis et al., 2018) and wool (Frei et al., 2009). The use of Sr isotopes in provenancing is based on measuring the ${ }^{87} \mathrm{Sr} /{ }^{86} \mathrm{Sr}$ ratio. $\mathrm{Sr}$ has four natural isotopes ${ }^{88} \mathrm{Sr},{ }^{87} \mathrm{Sr},{ }^{86} \mathrm{Sr}$ and ${ }^{84} \mathrm{Sr} .{ }^{87} \mathrm{Sr}$ is radiogenic, some is present when the rock is formed, but it also accumulates over geological timescales through the radioactive decay of ${ }^{87} \mathrm{Rb}$ (half-life $4.92 \times 10^{10}$ years). As such the modern ${ }^{87} \mathrm{Sr} /{ }^{86} \mathrm{Sr}$ ratio of a rock or deposit depends on the age and geological origin of the deposit, the Rubidium (Rb) and $\mathrm{Sr}$ concentrations and the original ${ }^{87} \mathrm{Sr} /{ }^{86} \mathrm{Sr}$ ratio. Regions dominated by relatively old and high silica (felsic) rocks will typically have highly radiogenic $\mathrm{Sr}$ isotope signatures $\left({ }^{87} \mathrm{Sr} /{ }^{86} \mathrm{Sr}=0.710\right.$ or higher) whereas regions dominated by younger and/or more juvenile mantle-derived material will have unradiogenic $\mathrm{Sr}$ isotope signatures $\left({ }^{87} \mathrm{Sr} /{ }^{86} \mathrm{Sr}=\right.$ 0.703-0.710). When using Sr isotopes as a provenance tracer, the assumption is that archaeological materials (for example plants, human and animal remains etc) inherit a Sr isotope signature that reflects the geological history of the region where the material formed.

Wood has played a major role in humans' societal and technological development: as a fuel for heating and cooking, to make tools, for decorative objects and for construction. This is the topic being addressed in the project 'Northern Europe's timber resource - chronology, origin and exploitation (TIMBER)', at the University of Copenhagen. Examining several timber structures across Northern Europe, from c. 1100 to $1700 \mathrm{CE}$, the archaeology, history, dating and provenance of these materials is being examined. Through analysis of numerous wooden archaeological remains dendrochronology and dendroprovenancing supplies us with detailed high-precision dating and pinpointing the origin of timber. This science focuses on using timbers with enough tree rings to determine the felling date of a tree to within a specific year (Bridge et al., 2012; Daly and Nymoen 2008), and also the provenance of the tree (Bridge, 2012; Daly 2007). There are, however, limits to these methods:

- Established chronologies (i.e. accumulated time-series of the annual variation in tree-ring width of a particular tree species/genus, built from analysis and cross-matching of large numbers of samples from living trees, historical buildings and archaeological sites in a region)

\footnotetext{
* Corresponding author. Saxo Institute, University of Copenhagen, Karen Blixens Plads 8, DK-2300, Copenhagen, Denmark.

E-mail address: alicia.vanhammeert@kuleuven.be (A. Van Ham-Meert).

1 Current address: Analytical, Environmental and Geo-Chemistry, Vrije Universiteit Brussel, Pleinlaan 2, B-1050, Elsene, Belgium.
} 


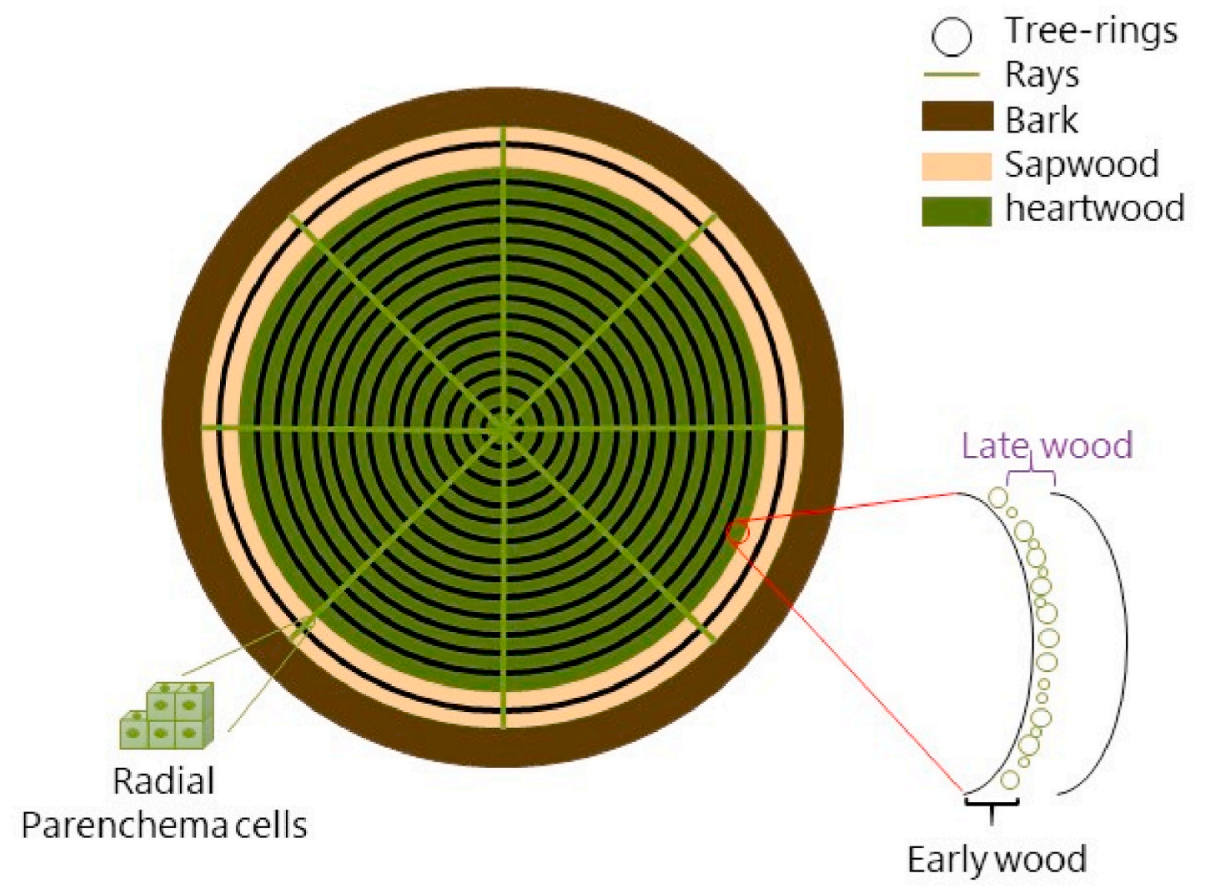

Fig. 1. Illustration of oak tree cell structure.

are needed to obtain cross-matching (i.e. to find a correspondence between the ring width sequence of the sample of unknown date and regional or site-based chronologies). For various reasons, chronologies do not yet exist for all species, regions and periods. In some regions, timber from historical remains yield only few examples of certain species. Furthermore, as we sample historical timber, we do not have information on how much a timber has been moved, before it ended up in a particular structure. Chronologies can therefore contain tree-ring data from trees imported into the region that the chronology is supposed to represent.

- Some chronologies are highly useful for dating (such as the chronologies built from analysis of oak used for painting supports, which has been shown to represent import of oak boards from the regions south and east of the Baltic Sea) but a precise geographical attribution is missing for those chronologies.

- When an object does not have enough tree-rings, the dendrochronological method cannot allow us to find its chronological position with established chronologies nor, therefore, the region of origin.

- The dendroprovenance method can identify provenance to a regional level, and only sometimes to the local level. Applying other scientific provenance identification techniques on dendrochronologically analysed wood could enable a refinement of the information we can gain, for study of the human past.

For these reasons, we wished to apply other scientific techniques that can be used to identify the provenance of ancient timber remains. In particular, to build-on and supplement the detail that dendrochronology offers. The Sr isotopic signature of timber materials reflects the substrate (rocks, soil, groundwater) they have grown on since trees incorporate $\mathrm{Sr}$ during growth (see section 1.1.). Thus, isotopic investigations of such materials can represent a theoretically useful means to determine if timber, used in human-built structures, was sourced locally, or was imported from elsewhere and provide us with extensive information on trading routes, manufacturing choices and agency.

Importantly, in order to make such interpretations it is essential to ensure that the isotopic signature in the wood reflects its original growth signature and has not been disturbed by later processes (whether during manufacture of the object or structure in the past, post-deposition, or through conservation). As timber is relatively porous, and archaeological timbers are often found buried or submerged, the possibility for removal and/or addition of $\mathrm{Sr}$ from groundwater and seawater is potentially problematic for identifying original chemical signatures. In this study, we focus on seawater contamination and investigate various techniques for removing this contamination.

\subsection{Strontium in wood}

Calcium and strontium are both bivalent alkaline earth metals with a similar ionic radius. As such, $\mathrm{Sr}$ can easily substitute for calcium in both organic and inorganic compounds. Similarly, Rb substitutes for potassium (K) as both are monovalent alkali metals of similar radii. Durand et al. (1999) performed chemical analysis (ICP-AES) of trees in Mexico, to see whether the underlying bedrock geology influenced the chemical composition of trees and whether there were differences in composition between different parts of the tree. Although they did not measure $\mathrm{Sr}$ and $\mathrm{Rb}$ content, they report $\mathrm{Ca}$ and $\mathrm{K}$ contents. Overall, in those samples Ca content was about 50000 ppm and K content 300-700 ppm, the bark being enriched in $\mathrm{K}$.

$\mathrm{Ca}$ is known to have a physiological role in trees, hence tree physiology controls the $\mathrm{Ca}$ concentrations and distribution across the tree (Blum et al., 2012). Sr on the other hand has no known physiological role. It simply enters the tree through the same channels as Ca without necessarily being eliminated. Thus, $\mathrm{Ca} / \mathrm{Sr}$ ratios of $241-1227$ are reported in foliage of trees of different species and growing within a $2 \mathrm{~km}$ radios of each other (Blum et al., 2012). Blum et al. (2012) also showed that most $\mathrm{Ca}$ and $\mathrm{Sr}$ present in foliage is taken-up through the shallow root systems, rather than the deep roots. As such, for predicting the isotopic composition of trees growing in a specific location, analysing the topsoil and groundwater responsible for most of the Sr uptake is the best way forward. This proves the usefulness of using regional scale mapping of bio-available $\mathrm{Sr}$ (and its isotopic composition) in topsoil and groundwater as a comparative proxy for archaeological timber provenance studies. This has been an important focus of recent work within the $\mathrm{Sr}$ isotope community, especially in North-West Europe for human 
Table 1

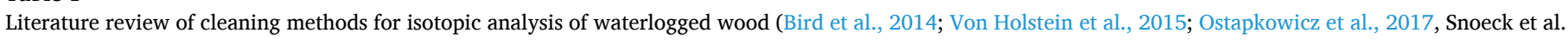
submitted, Brinkkemper et al., 2018; Rich et al. 2012, 2016a; Million et al., 2018; Andreu-Hayles et al., 2019; Büntgen et al., 2020).

\begin{tabular}{|c|c|c|c|c|}
\hline Material & cleaning procedure & system & assessment & reference \\
\hline Charcoal & $\begin{array}{l}\text { ABA } \\
\text { Abox } \\
\text { Hydrogen Pyrolysis }\end{array}$ & $\begin{array}{l}\text { radio- } \\
\text { carbon }\end{array}$ & $\begin{array}{l}\text { less efficient than } \mathrm{ABOX} \\
>94 \% \text { exo removed } \\
\text { worst of the } 3\end{array}$ & Bird et al. (2014) \\
\hline $\begin{array}{l}\text { archaeological wool, dyed \& undyed replicates, } \\
\text { buried in bog \& marine sediment }\end{array}$ & $\begin{array}{l}\text { No cleaning } \\
\text { High pressure } \mathrm{N}_{2}\end{array}$ & $\mathrm{Sr}$ & $\begin{array}{l}\text { able to retrieve original signature } \\
\text { of undyed sample }\end{array}$ & $\begin{array}{l}\text { Von Holstein et al. } \\
\text { (2015) }\end{array}$ \\
\hline & $\begin{array}{l}\mathrm{HF} \\
\mathrm{HF}+\text { oxidising agent (dyed samples only) } \\
\text { Organic solvents }\end{array}$ & & best at removing exogeneous $\mathrm{Sr}$ & \\
\hline waterlogged pine & $\begin{array}{l}\text { organic solvents to remove conservation } \\
\text { materials followed by ABA \& bleach }\end{array}$ & $\begin{array}{l}\text { radio- } \\
\text { carbon }\end{array}$ & & $\begin{array}{l}\text { Ostapkowicz et al. } \\
\text { (2017) }\end{array}$ \\
\hline $\begin{array}{l}\text { waterlogged pine } \\
\text { charred plants }\end{array}$ & $\begin{array}{l}\text { various } \\
\text { MQ } \\
\text { A-only } \\
\text { ABA }\end{array}$ & $\begin{array}{l}\mathrm{Sr} \\
\delta^{13} \mathrm{C} \\
\& \delta^{15} \mathrm{~N}\end{array}$ & $\begin{array}{l}\text { Snoeck et al. Submitted } \\
\text { good results } \\
\text { most material loss }\end{array}$ & $\begin{array}{l}\text { Brinkkemper et al., } \\
2018\end{array}$ \\
\hline $\begin{array}{l}\text { living cedar trees } \\
\text { archaeological wood (on land and waterlogged) } \\
\text { waterlogged fir \& oak (river) } \\
\text { Wood }\end{array}$ & $\begin{array}{l}\text { No cleaning } \\
\text { wash } \\
\text { water wash } \\
\text { alpha-cellulose extraction }\end{array}$ & $\begin{array}{l}\mathrm{Sr} \\
\mathrm{Sr} \\
\mathrm{Sr} \\
\delta^{13} \mathrm{C} \\
\& \delta^{18} \mathrm{O}\end{array}$ & & $\begin{array}{l}\text { Rich et al. (2012) } \\
\text { Rich et al. (2016a) } \\
\text { Million et al. (2018) } \\
\text { Andreu-Hayles et al., } \\
2019\end{array}$ \\
\hline Wood & alpha-cellulose extraction & $\begin{array}{l}\delta^{13} \mathrm{C} \\
\& \delta^{18} \mathrm{O}\end{array}$ & & Büntgen et al. (2020) \\
\hline
\end{tabular}

migration studies (Blank et al., 2018; Wilmes et al., 2018; Hoogewerff et al., 2019; Ladegaard-Pedersen et al., 2020; Snoeck et al., 2020). Some recent discussion also focussed on the influence of modern anthropogenic activities (industrial and agricultural), which might lead to modern maps not reflecting the situation in ancient times (Drouet et al., 2005; Maurer et al., 2012, Frei et al., 2020).

The most important findings on the presence and concentration of $\mathrm{Sr}$ and $\mathrm{Ca}$ in (living) trees can be summarised as follows. Based on their observation that $\mathrm{Mn}, \mathrm{Sr}$ and $\mathrm{Mg}$ concentrations in trees are lower when large floods occur, St. George et al. (2006) suggest these elements might be stored in the tyloses of the tree. Ca, present as Ca-oxalate, precipitates in bark (Serdar and Demiray 2012). Serdar and Demiray (2012) investigated the form of calcium oxalate crystals in oak trees. They showed that: (1) trees from the same species in different locations have different calcium oxalate concentrations; (2) the crystals are mainly present in axial parenchyma cells, uniseriate ray cells and late wood vessels; (3) Ca-oxalates were mostly present as whewellite i.e. Ca-oxalate monohydrate: $\mathrm{CaC}_{2} \mathrm{O}_{4} \cdot \mathrm{H}_{2} \mathrm{O}$ of which tetragonal $\mathrm{Sr}$-oxalate is an isomorph (Serdar and Demiray 2012). Calcium is also found in cell walls particularly in pectin, cellulose and lignin (Hajj et al., 2018). Fig. 1 illustrates a slice of an oak trunk to illustrate the main concepts and structures present in a trunk.

\subsection{Strontium isotopic composition of (waterlogged) wood}

For cedar wood, it has been shown that there was no fractionation of $\mathrm{Sr}$ isotopes between early heartwood, heartwood, sapwood and twig wood (Rich et al., 2016a). Rich et al. (2016a) showed that the Sr isotopic signature of trees is affected by seaspray (in Cyprus), the substrate on which the trees grow, weathering and ground water. One of the conclusions of the work is also that there is a need for a systematic study to determine to what extent there might be an influence of diagenetic Sr, especially in investigations of timber in shipwrecks (Rich et al., 2016a).

In oaks, the $\mathrm{Sr}$ concentration is higher in sapwood than in heartwood. Furthermore, on an annual level Sr (and other alkaline earth metals) concentrations are increased in early wood compared to late wood (St. George et al., 2006). However, it is important to note here that this should have no consequence for $\mathrm{Sr}$ isotopic compositions. The concentration of $\mathrm{Sr}$ in trees can be affected by anthropogenic liming (which has occurred at least since the 19th century) as well as acidification (St. George et al., 2006) - and this can potentially have an influence on $\mathrm{Sr}$ isotopic compositions due to addition of $\mathrm{Sr}$ from different geological sources (primarily limestone in the case of liming) (Thomsen and Andreasen 2019; Frei et al., 2020).

Submersion of wood will result in exchange of chemical components with the surrounding water and mask primary signatures. The Sr concentration of seawater is about $8 \mathrm{ppm}$, in river water it is about $50 \mathrm{ppb}$ (Brems et al., 2013; Steelandt et al., 2016). There are both crustal (weathering) and mantle (volcanic) contributions to the total $\mathrm{Sr}$ in sea water. Hence seawater ${ }^{87} \mathrm{Sr} /{ }^{86} \mathrm{Sr}$ signatures varied over time. Today its value is 0.7092 and it is homogeneous over the planet and over archaeological timescales. This homogeneity arises from the length of its residence time in the ocean ( 5 million years), compared to the average time needed for mixing the ocean (1500 years) (Brems et al., 2013). The main contributions of $\mathrm{Sr}$ in river systems are weathering of the local bedrock and rainfall and runoff water, therefore, the $\mathrm{Sr}$ isotopic composition of rivers varies geographically (depending on the local bedrock inputs and precipitation).

Steelandt et al. (2016) performed some experiments to determine the influence of waterlogging on the elemental composition of wood. They placed wood samples for a week in the Hudson River and noted a 3-fold increase of the bulk Sr concentration after just one week in the river. Hajj et al. (2018) placed archaeological wood from Segovia cathedral in seawater and noted a 10 -fold increase in $\mathrm{Sr}$ after waterlogging for three months. This clearly proves that waterlogging significantly contributes to the overall $\mathrm{Sr}$ content in wood and hence there is a large proportion of exogenous $\mathrm{Sr}$ in waterlogged-wood. Spatially-resolved analysis of archaeological oak wood from a shipwreck showed that outer parts of the wood had a composition close to the sea-signature $\left({ }^{87} \mathrm{Sr} /{ }^{86} \mathrm{Sr}=\right.$ 0.70909-0.70916), whereas the internal part had a lower signature (0.70871-0.70883). This was attributed to the deposition of secondary minerals during the water burial period (Hajj et al., 2018).

Another possible source of exogeneous $\mathrm{Sr}$ can come in the form of fungi. Brown rot fungi in particular, produce Ca-oxalates using both material from the wood and external material (Hajj et al., 2018). These oxalates are not visible to the naked eye. Since Sr easily substitutes for $\mathrm{Ca}$ and those oxalates incorporate at least some exogenous material, wood with visible alteration due to fungi should be avoided (Connolly et al., 1999).

Apart from possible exogenous material entering the wood or shells growing on timbers in the sea, the degradation and preservation of the timbers is also of importance when trying to identify original signatures. 
During immersion in seawater there usually is little bacterial degradation of the wood. Once the timbers are lifted out of the water and come in contact with oxygen, bacterial degradation occurs rapidly. During waterlogging, polysaccharides are hydrolysed and leached out whilst lignin is preserved (Traoré et al., 2018). In fact, lignin is the major component of wood after waterlogging (Traoré et al., 2018). The preserved lignin seems thus a promising part of the wood to find the original Sr signature.

Seeing all the possible influences on the final $\mathrm{Sr}$ isotopic composition in waterlogged wood, it seemed relevant to perform some experiments in order to assess whether it is possible to retrieve the original Sr isotopic composition of wood. The applied methods are informed by the current understanding on how Sr finds its way into archaeological wood, how degradation occurs and (the relatively limited) experiments that have been already performed in literature (see next point).

\section{Review of existing cleaning methods}

Recently, cleaning methods to remove exogenous components were compared for Sr isotopic analysis of wool (Von Holstein et al., 2015). The authors hypothesized that Sr was most probably present as either metal mercaptides, nano-crystalline sulphides or on exchangeable sites (such as carboxyl groups) (Von Holstein et al., 2015). Those exchangeable sites are often $\mathrm{pH}$ sensitive but also most prone to exchange with exogenous Sr. Von Holstein et al. (2015) tested many cleaning methods on both archaeological and experimental set-ups reported in Table 1. The conclusion from this work was that none of the tried methods completely remove exogeneous $\mathrm{Sr}$, with the exception of using compressed $\mathrm{N}_{2}$ on undyed wool (Von Holstein et al., 2015).

For radiocarbon dating of waterlogged wood, acid-base-acidbleaching (ABA) is typically used to remove exogeneous components (Brock et al. 2010 in Lorentzen et al., 2014). However, the particulars of the cleaning methods used (molarity of the solution, duration and temperature of the treatment) vary between different labs (see ESI 1).

As far as Sr isotopic analysis of waterlogged wood is concerned, only a few attempts are known in literature, often without much attention to the pre-treatment. The only information on the pre-treatment given by Rich et al. (2016b) is "samples were washed to remove precipitates" with no details given on the types of reagents used, or the lengths of times used (though it seems ultrapure Milli-Q water (MQ)was used). As the Sr isotopic results for the Uluburun shipwreck yield results close to the seawater-range (0.70919-0.70923), this cleaning might in fact not have been enough to remove the seawater component. The Sr-isotope results for the Athlit Ram, another shipwreck in the same paper, are $0.70891-0.70894$, which is slightly lower than the seawater signature but very close to the local rainfall signature (Hartman and Richards 2014). Apart from waterlogging, trees growing near the shore are also affected by seaspray, resulting in compositions that diverge from the local substrate (Rich et al., 2012).

Million et al. (2018) performed Sr isotopic analysis on archaeological waterlogged fir and oak (from the Danube River) as well as soil samples and living trees. The archaeological waterlogged wood cleaned with only water has a $\mathrm{Sr}$ isotope signature between 0.70888 and 0.70962 , considerably lower than the substrates (0.72073-0.72117). Million et al. (2018) do not report a Sr isotope composition for the Danube River water, but measurements by Palmer and Edmond (1989) yielded a value of 0.7089 . From the comparison between the composition of the Danube River water and the "cleaned" wood we conclude its signature is still influenced by the Sr of the Danube River and therefore, this cleaning was presumably not sufficient. Toxvaerd et al. (2020) recently published and article on the challenges of determining the $\mathrm{Sr}$ isotopic composition in organic materials preserved under anaerobic acidic conditions.

\section{Materials and methods}

\subsection{Materials}

To examine the influence of immersion of wood in varying waterlogging environments a large modern tree trunk was sampled. The tree was felled in 2017 to be used at the Viking Ship Museum in Roskilde, Denmark for constructing a replica Viking ship. It grew in Jægersborg Hegn, North of Copenhagen on the island of Sjælland in Denmark. Slices were kindly taken, by the Museum, and donated to the TIMBER project, of two trees, to enable a dendrochronological analysis throughout the tree, from base to branch. For the immersion experiment, sub-samples from the heartwood were taken from 'tree 2', in 20-ring blocks. The outer wood layers of all exposed surfaces were removed with a precleaned (ethanol) razor blade. A piece of this trunk (ca. $3 \times 3 \times 8 \mathrm{~cm}$ ) was immersed in 21 of unfiltered seawater from the Baltic Sea (sampled at Amager Beach in Copenhagen, Denmark). Water samples were collected in pre-cleaned PVC bottles that were conditioned with the natural water samples. The submerged timber samples were first sampled after three months of experimental waterlogging; water samples were also taken at that time. A single archaeological waterlogged timber was also included in the analysis: it is a sub-sample of a dendrochronology sample of a plank from a wreck found at Peenemündung, Germany (Ostsee VII, Fpl 105) and is designated 'PLK 315' for this analysis. The wreck was surveyed by Jens Auer and his team, Landesamt für Kultur und Denkmalpflege, Mecklenburg-Vorpommern (Dalicsek et al., 2018; Steffensen 2019) and the dendrochronological analysis demonstrates that the ship is built of trees that grew in the region around Gdansk, felled around 1420 CE (Daly 2019). According to the maps provided Hoogewerff et al. (2019) the Sr isotopic signature in that region is $0.710-0.713$ depending how far up the Vistula river the trees grew. During analysis, two reference materials were also included: NIST SRM 987 (a Sr carbonate reference material commonly used in the geosciences) for the TIMS analysis and, the NIST 1515 apple leaf standard as a procedural reference material.

\subsection{Methods}

For each of the cleaning methods a subsample of 500-1000 mg of dried wood was used as starting material. As others have already tried a number of pre-treatments for waterlogged wood (Snoeck et al. forthcoming) notably ABA, we limited ourselves to the following treatments: Ashing of the wood samples $\left(16 \mathrm{~h}\right.$ at $\left.400{ }^{\circ} \mathrm{C}\right)$; multiple washes with MQ; a combination of MQ and hydrofluoric acid (HF) cleanings similar to the procedures used by Von Holstein et al. (2015) for cleaning wool with 30-60 min sonication for each step; and alpha-cellulose extraction following the method modified from Andreu-Hayles et al. (2019) for oxygen stable isotope analysis in wood.

Ashing was performed in individual porcelain crucibles with lids for $16 \mathrm{~h}$ at $400{ }^{\circ} \mathrm{C}$ in a Nabertherm L5 11/C6D oven under atmospheric pressure and air flow. The ashed samples were collected from the crucibles by adding MQ to the cooled crucible and transferring it to Savilex ${ }^{\circledR}$ beakers for digestion. When the crucibles were opened great care was needed to avoid losing too much ash.

The alpha-cellulose extraction consists of six 1-h treatments with $\mathrm{NaClO}_{2}$ at $80{ }^{\circ} \mathrm{C}$ in closed Savillex ${ }^{\circledR}$ vials on a hotplate (the leaching solution is changed every hour, the supernatant was removed with a pipette so that the sample would remain in the Savillex ${ }^{\circledR}$ vial for further treatment). Subsequently, the sample was treated for $45 \mathrm{~min}$ at $70{ }^{\circ} \mathrm{C}$ with $10 \% \mathrm{NaOH}, 45 \mathrm{~min}$ at room temperature in $17 \% \mathrm{NaOH}$ and finally two 1-h treatments with $\mathrm{NaClO}_{2}$ at $80{ }^{\circ} \mathrm{C}$. Between each step the remaining wood is thoroughly rinsed with MQ water. Waterlogged wood starts out black and by the time only alpha-cellulose is left it is white. During the procedure, leachates were also kept in order to determine $\mathrm{Sr}$ concentration and isotopic composition of the removed material.

After cleaning, the wood was dissolved overnight in $4 \mathrm{ml} \mathrm{1:1} \mathrm{mixture}$ 
Table 2

Isotopic composition (with 2SD) of waters used for waterlogging, modern wood samples and the Gdànsk region.

\begin{tabular}{lll}
\hline & ${ }^{87} \mathrm{Sr} /{ }^{86} \mathrm{Sr}$ & $2 \mathrm{SD}$ \\
\hline modern tree & 0.71382 & 0.00010 \\
waterlogged modern tree & 0.70959 & 0.00002 \\
Gdansk region (est. From Hoogewerf et al. 2019) & $0.710-0.713$ & \\
Amager Beach water & 0.70929 & 0.00001 \\
Ise fjord water & 0.70919 & 0.00001 \\
\hline
\end{tabular}

of $14 \mathrm{M} \mathrm{HNO}$ and $30 \% \mathrm{H}_{2} \mathrm{O}_{2}$ at $130{ }^{\circ} \mathrm{C}$ in capped Teflon beakers, following the digestion procedure of Hajj et al. (2018). The solution was evaporated and then taken up in $1 \mathrm{ml} 3 \mathrm{M} \mathrm{HNO}_{3}$. An ${ }^{84} \mathrm{Sr}$-spike $\left(2.490175 \mathrm{nmol}{ }^{84} \mathrm{Sr} / \mathrm{g} ;{ }^{84} \mathrm{Sr} /{ }^{86} \mathrm{Sr}=23.2399\right)$ solution is added, before column chromatography, to determine the $\mathrm{Sr}$ concentration. Sr was purified using Sr-spec resin in single use columns as described elsewhere (Charlier et al., 2006). Even with the hydrogen-peroxide based dissolution some organics were still present. Following column chmistry, the isolated solution was evaporated, loaded on Re-filaments with a Ta activator and placed in a MC-TIMS (Sector 54 TIMS instrument) operated in dynamic mode. The samples were outgassed before running them. Each run consisted of 10 blocks of 10 cycles (a total of 100 ratios measured for each sample), between blocks the filament current was adjusted, if needed, to attain the pre-selected intensity of $1 \mathrm{~V}$ for ${ }^{88} \mathrm{Sr}$. For a few samples (especially the ashed samples and some of the reagents) this was not possible leading to large errors due to lower intensities and fewer measurement points. The TIMS automatically corrects for mass bias using the exponential law and ${ }^{86} \mathrm{Sr} /{ }^{88} \mathrm{Sr}=0.1194$. The isobaric interference from $\mathrm{Rb}$ is corrected for by monitoring the intensity of ${ }^{85} \mathrm{Rb}$ and assuming a natural ${ }^{87} \mathrm{Rb} /{ }^{85} \mathrm{Rb}$. If there is a high $\mathrm{Rb}$ content, the filament is quickly heated and $\mathrm{Rb}$ is burnt off manually (it vaporizes more easily than $\mathrm{Sr}$ ) before proceeding to the analysis. On each turret (i. e. each batch of samples) a filament loaded with NIST SRM 987 $\left({ }^{87} \mathrm{Sr} /{ }^{86} \mathrm{Sr}=0.710248\right.$ - Weis et al., 2006) is added to monitor the instrumental bias. The value for this experiment is reported in Table 6 .

\section{Results \& discussion}

\subsection{Sr isotopic composition of raw materials}

Sr isotope composition results for the various starting materials and treatment experiments are presented in Table 2. For the archaeological sample PLK 315, the dendrochronological analysis indicated a provenance from the Gdansk region, Reagents, including MQ water, were also measured but their Sr contents upon analysis were close to blank values, with meaningless $\mathrm{Sr}$ isotopic results (measurement uncertainty on the 3rd decimal). The uncertainty on the fresh wood arises not from one analysis but from the average of three analyses with different treatments of the wood (after MQ rinses, after HF and MQ rinses and after ashing). As such it accounts for both small scale heterogeneities within the wood and possible effects of leaching. The $\mathrm{Sr}$ isotopic composition of the waterlogged timber is also reported, it was measured after ashing, which

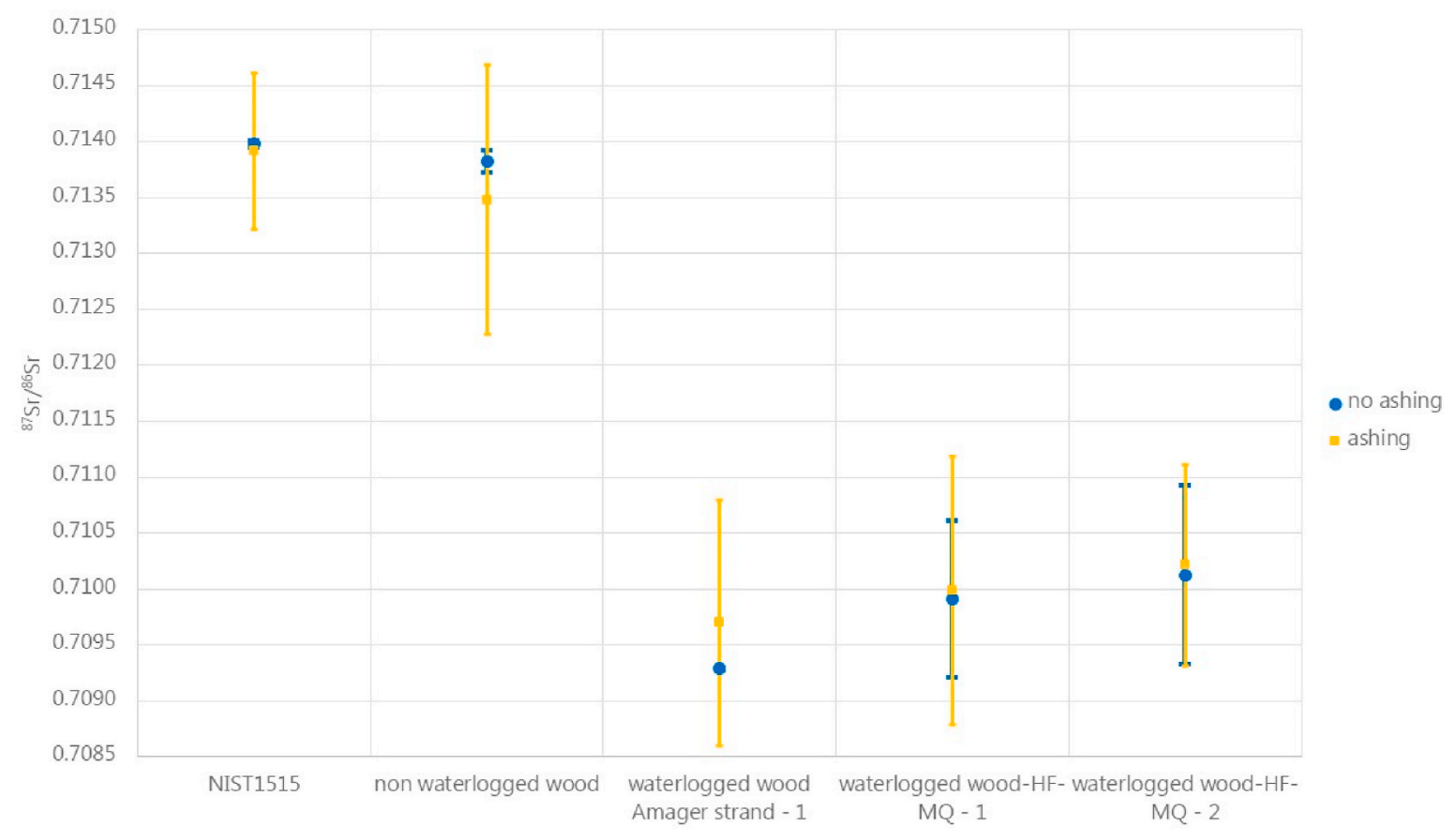

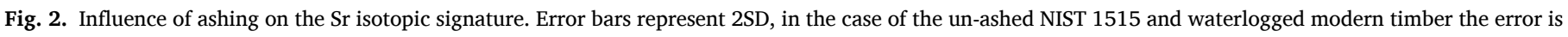
smaller than the marker.

Table 3

Sr-isotope results of ashing experiments, 2SD are also reported, note the larger uncertainties associated to the ashing experiments.

\begin{tabular}{|c|c|c|c|c|c|}
\hline \multirow[t]{2}{*}{ Sample } & \multirow[t]{2}{*}{ Treatment } & \multicolumn{2}{|l|}{ no ashing } & \multicolumn{2}{|l|}{ ashing } \\
\hline & & ${ }^{87} \mathrm{Sr} /{ }^{86} \mathrm{Sr}$ & $2 S D$ & ${ }^{87} \mathrm{Sr} /{ }^{86} \mathrm{Sr}$ & $2 S D$ \\
\hline NIST1515 & & 0.71398 & 0.00003 & 0.71391 & 0.00070 \\
\hline Wood & none & 0.71382 & 0.00010 & 0.71348 & 0.00120 \\
\hline waterlogged wood Amager strand - 1 & waterlogging & 0.70929 & 0.00001 & 0.70970 & 0.00110 \\
\hline waterlogged wood-HF-MQ - 1 & waterlogging - 1h MQ - 1h HF & 0.70991 & 0.00070 & 0.70999 & 0.00120 \\
\hline waterlogged wood-HF-MQ - 2 & waterlogging - 1h MQ - 1h HF & 0.71012 & 0.00080 & 0.71021 & 0.00090 \\
\hline
\end{tabular}



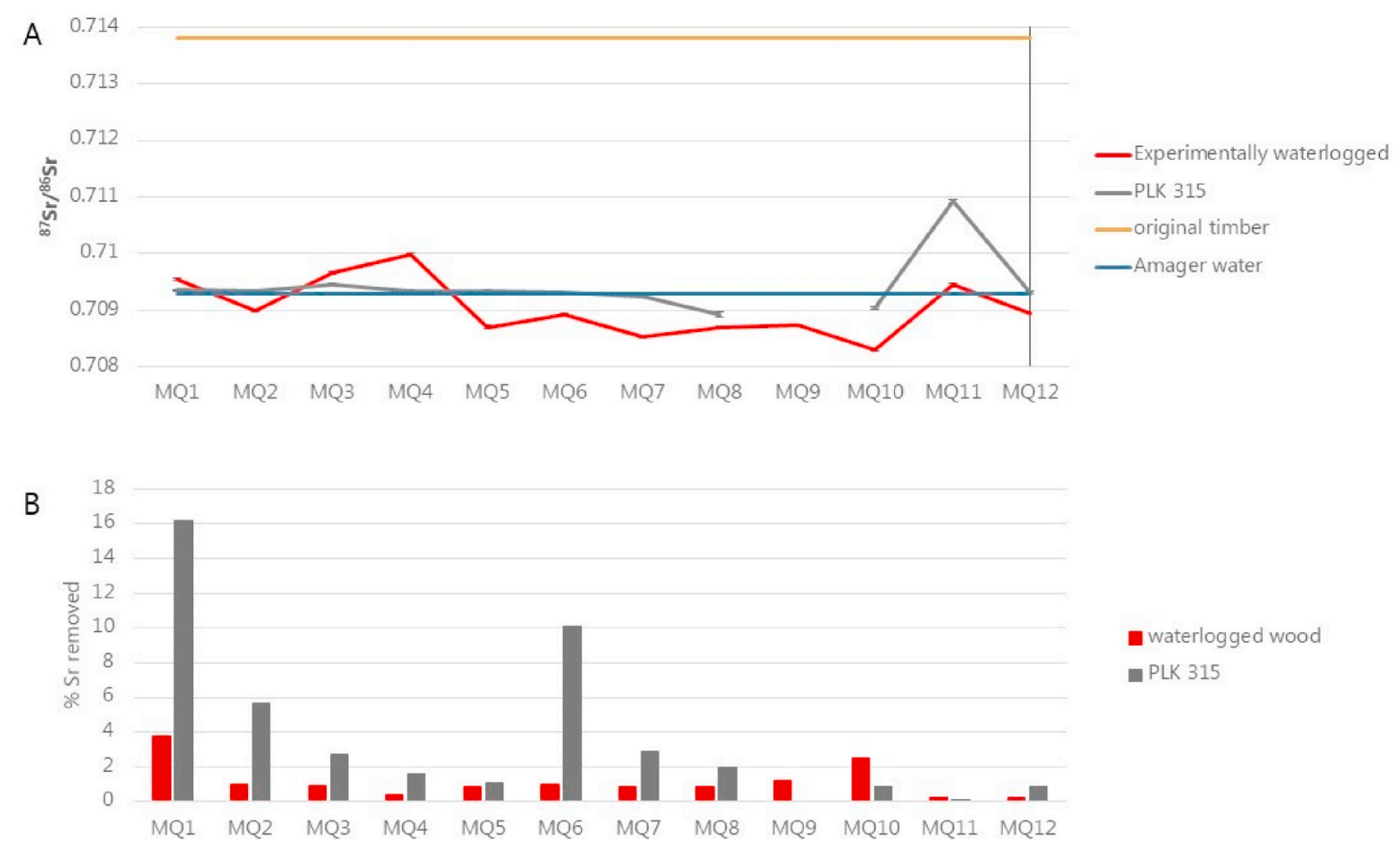

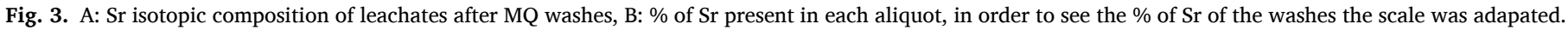
Error bars represent 2sd and are mostly smaller than the symbol size.

Table 4

Sr isotopic composition (with 2SD) of the MQ washes (MQ1-12). Pt 1 and 2 are two subsamples of the wood taken between the 10th and 11th and after the 12th washes, respectively.

\begin{tabular}{|c|c|c|c|c|c|c|c|c|}
\hline & \multicolumn{4}{|c|}{ Experimentally waterlogged } & \multicolumn{4}{|l|}{ PLK 315} \\
\hline & ${ }^{87} \mathrm{Sr} /{ }^{86} \mathrm{Sr}$ & 2SD & ppm Sr removed & $\%$ removed & ${ }^{87} \mathrm{Sr} /{ }^{86} \mathrm{Sr}$ & 2SD & ppm Sr removed & $\%$ removed \\
\hline MQ1 & 0.70955 & 0.00002 & 0.41 & 3.81 & 0.70936 & 0.00001 & 5.75 & 16.15 \\
\hline MQ2 & 0.70900 & 0.00003 & 0.11 & 1.02 & 0.70934 & 0.00002 & 2.01 & 5.65 \\
\hline MQ3 & 0.70966 & 0.00002 & 0.1 & 0.93 & 0.70945 & 0.00002 & 0.96 & 2.70 \\
\hline MQ4 & 0.70999 & 0.00003 & 0.04 & 0.37 & 0.70933 & 0.00003 & 0.56 & 1.57 \\
\hline MQ5 & 0.70870 & 0.00003 & 0.09 & 0.84 & 0.70934 & 0.00002 & 0.39 & 1.10 \\
\hline MQ6 & 0.70892 & 0.00002 & 0.11 & 1.02 & 0.70931 & 0.00001 & 3.59 & 10.08 \\
\hline MQ7 & 0.70853 & 0.00002 & 0.09 & 0.84 & 0.70924 & 0.00001 & 1.03 & 2.89 \\
\hline MQ8 & 0.70869 & 0.00002 & 0.09 & 0.84 & 0.70892 & 0.00005 & 0.71 & 1.99 \\
\hline MQ9 & 0.70873 & 0.00002 & 0.13 & 1.21 & & & & \\
\hline MQ10 & 0.70829 & 0.00002 & 0.27 & 2.51 & 0.70904 & 0.00002 & 0.31 & 0.87 \\
\hline pt 1 & 0.70974 & 0.00004 & 2.56 & 23.79 & 0.70942 & 0.00003 & 6.15 & 17.28 \\
\hline MQ11 & 0.70945 & 0.00776 & 0.03 & 0.28 & 0.71093 & 0.00002 & 0.01 & 0.03 \\
\hline MQ12 & 0.70894 & 0.00018 & 0.03 & 0.28 & 0.70932 & 0.00096 & 0.3 & 0.84 \\
\hline pt2 & 0.70982 & 0.00002 & 6.7 & 62.27 & 0.70931 & 0.00002 & 13.83 & 38.85 \\
\hline
\end{tabular}

explains the larger uncertainty. It is indistinguishable within error of the seawater signature.

\subsection{Ashing}

Ashing is often performed in order to remove the organic fraction of the wood. Sr is present in the mineral fraction of wood, and the organic fraction complicates the elution of Sr during chromatography, so getting rid of this fraction is desirable. Fig. 2 shows the influence of ashing on the isotopic composition. In this experiment, $\mathrm{Sr}$ isotopic analysis of ashed and non-ashed material was determined. Both "fresh" material (reference material NIST 1515 and unwaterlogged wood) and waterlogged material (the three immersed sub-samples from the recent oak) were analysed. The main observation is that after ashing the measurement uncertainty increases between 10 and 20 times on the fresh material and by $20 \%$ for the waterlogged cleaned material (Table 3 ). The large uncertainty is due to the loss of material during ashing, and thus lower amounts of Sr available for analysis. In Fig. 2, the errors on the non-ashed fresh material are smaller than the marker, whereas on the non-ashed cleaned waterlogged material they are larger. This is attributed to loss of material during cleaning; more discussion of this is given in the subsequent sections. We note that care needs to be taken when collecting material following ashing as it can easily be lost from the crucible. It seems thus that since collecting the ash is complicated and resulting uncertainties are increased, ashing should be avoided in the analysis of archaeological material. Larger samples might mitigate this problem, but in general in archaeological research we strive to be as non-invasive as possible, and hence smaller samples are preferred.

\subsection{Consecutive $M Q$ washes}

A series of consecutive MQ washes were done on both the modern waterlogged wood and the archaeological wood from the ship plank PLK 315, the results of which are plotted in Fig. 3 and reported in Table 4. 


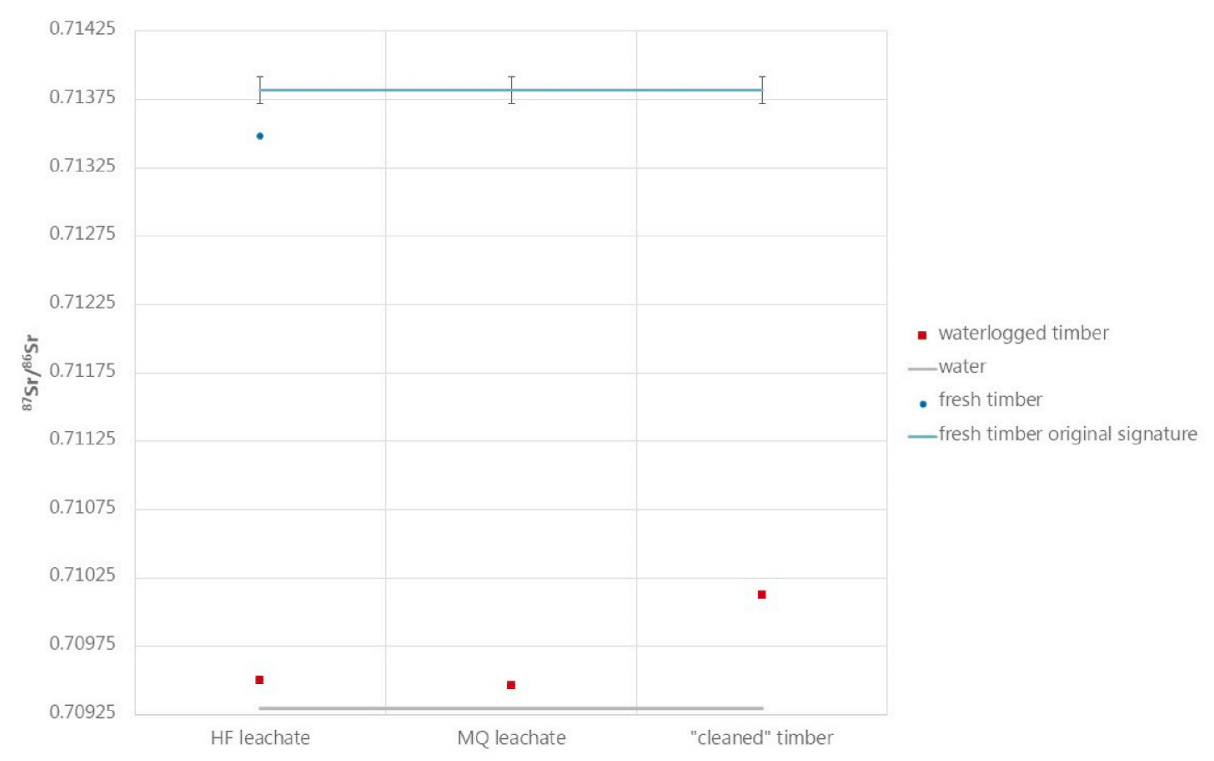

Fig. 4. Effect of MQ- and HF-cleanings on the Sr isotopic signature of experimentally waterlogged wood and of fresh timber, internal errors $2 \mathrm{SD}$ are smaller than the marker, the uncertainty on the signature of the fresh timber is included.

The first 10 experiments (MQ1 to MQ10) consisted of $2 \mathrm{~h}$ of sonication in MQ water, and each individual leachate was measured. After those ten washes a subsample of the wood was taken for processing and analysis (pt 1). This procedure was designed to check how much Sr was left in the wood after those washes and whether 10 washes was enough to remove the exogeneous Sr. Since the composition of this aliquot was still very distinct from the original (i.e. fresh timber) signature, further cleanings were undertaken in two steps of 12h-long sonications (MQ11 and MQ12) and a new sub sample was taken (pt 2). Although the compositions of the experimentally waterlogged wood after this prolonged MQ leach is marginally closer to the real wood signature $(0.71382 \pm$ 0.00010 ) it is still significantly different. The experiment was interrupted by the temporary closing of the university in March 2020. However, since after so many washes the original signature was still not recovered, it is uncertain this would have been achieved by this method. Especially since during leachates 11 and 12 hardly any additional Sr was removed.

In Fig. 3A, the signature of each of the leachates and the subsamples is shown and compared with the seawater signature and the original fresh timber signature. To have an idea of the proportion of Sr removed in each leachate, the sum of all the $\mathrm{Sr}$ concentrations in each step was compared to the overall Sr content (based on the sum of each step, both leachates and subsamples) and represented in \% in Fig. 3B. As the two subsamples contain most of the Sr (indicating that the washes are not removing most of the $\mathrm{Sr}$ ), the scale was adapted.

The $\mathrm{Sr}$ isotopic signature is more radiogenic than the seawater signature for leachates MQ3-MQ4 and MQ 11 of the experimentally waterlogged wood and for all the archaeological leachates except MQ7, MQ8 and MQ 10. This points towards the possibility that both exogeneous and original $\mathrm{Sr}$ are being leached during the cleaning procedure.

Even if complete removal of exogeneous $\mathrm{Sr}$ were to be achieved, the amount of work needed to obtain the original wood signature would make such analysis expensive and time-consuming. This is most clearly illustrated in Fig. 3B; in the experimentally waterlogged wood more than $60 \%$ of the Sr and in the archaeological wood more than $35 \%$ of the $\mathrm{Sr}$, remain present after 12 leaches (and in total $44 \mathrm{~h}$ of sonication, in practice about a week of labwork), whereas the proportion of $\mathrm{Sr}$ removed with each new leaching decreases (Fig. 3B). Furthermore, as noted above, part of the endogeneous $\mathrm{Sr}$ is also removed during
Table 5

Sr-isotopic signatures (with 2SD) of leachates and wood after MQ- and HFwashes.

\begin{tabular}{|c|c|c|c|c|}
\hline & \multicolumn{2}{|c|}{ waterlogged timber } & \multicolumn{2}{|c|}{ fresh timber } \\
\hline & ${ }^{87} \mathrm{Sr} /{ }^{86} \mathrm{Sr}$ & $2 \mathrm{SD}$ & ${ }^{87} \mathrm{Sr} /{ }^{86} \mathrm{Sr}$ & 2SD \\
\hline HF leachate & 0.70950 & 0.00001 & 0.71348 & 0.00001 \\
\hline MQ leachate & 0.70947 & 0.00001 & & \\
\hline timber after MQ and HF wash & 0.71012 & 0.00001 & & \\
\hline
\end{tabular}

leaching, so further leaches will also jeopardise the possibility to retain any endogeneous Sr. These low removals of Sr lead to large measurement errors on the Sr isotopic measurements (MQ11 and 12 of the archaeological timber in particular). From this experiment it is also clear that archaeological and experimentally waterlogged wood behave differently during the cleaning procedure, notably more $\mathrm{Sr}$ is removed from the archaeological than from the experimental wood.

\section{4. $M Q-H F$}

Fig. 4 and Table 5 represent another set of experiments, where first the wood was leached in HF for $1 \mathrm{~h}$ and then in MQ. Furthermore, the effect of an HF leaching on the Sr isotopic composition of fresh timber is also shown. The leachates of the waterlogged timber have a slightly more radiogenic (i.e. containing relatively more ${ }^{87} \mathrm{Sr}$ ) signature than the seawater from the Baltic Sea collected at Amager Beach (Copenhagen, Denmark) - suggesting removal of a more radiogenic Sr component from the wood, and that the leaching procedure was aggressive enough to also remove some of the primary $\mathrm{Sr}$ from the wood. Clearly, too much or too aggressive leaching may lead to complete leaching of the original $\mathrm{Sr}$. After the cleaning procedure, the timber Sr isotopic signature has shifted to more radiogenic compositions, however it remains significantly lower than the pre-waterlogged composition.

We would expect any leachates of fresh timber to reflect the Sr isotopic composition of the timber. However, the HF leachate is slightly less radiogenic than the original timber. This might indicate that HF only accesses certain reservoirs of $\mathrm{Sr}$ in the wood, rather than the bulk Sr. 


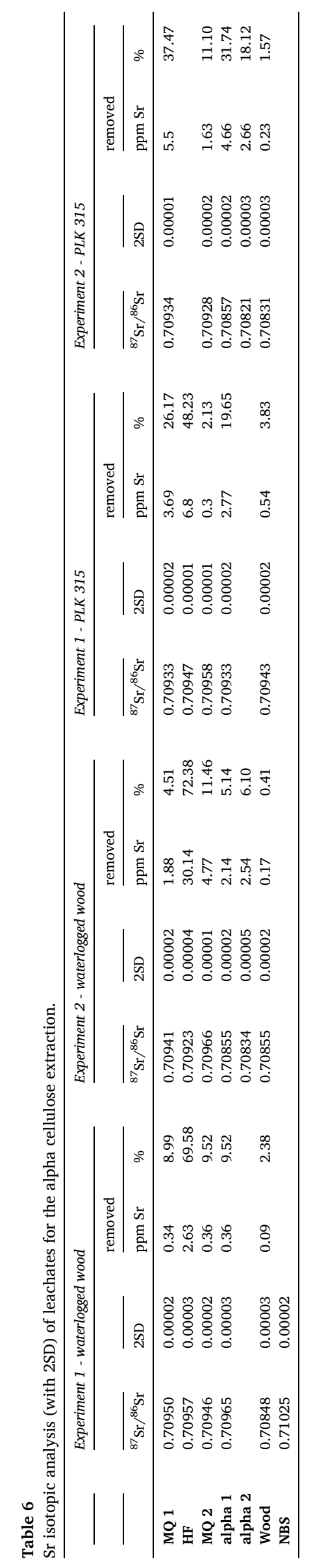

\subsection{Alpha-cellulose extractions}

Two different sets of alpha-cellulose cleaning trials were performed. The method consisted of $1 \mathrm{~h}$ of sonication each in MQ, HF and then again MQ and then alpha-cellulose extraction. In the second experiment, the leachates from alpha cellulose were divided in two. Alpha-1 consists of the first $6 \mathrm{NaClO}_{2}$ treatments, the subsequent treatments are compiled in alpha-2. The results are plotted in Fig. 5, the left figure is the experimentally waterlogged wood and the right figure is archaeological wood (for which there is no reference composition). The first observation is that the two cleaning trials did not yield the same results in the leachates. In the experimentally waterlogged modern wood, at the end of both cleaning experiments the wood has the same isotopic signature (below seawater signature). Whereas the signatures of the individual leachates vary between both experiments, and the second set of experiments shows a similar pattern for both the archaeological and experimentally waterlogged wood. The final signature being below the seawater signature is enigmatic especially from a mass balance perspective. One possible explanation for this is that fractionation could be occurring between different cell-types in the (original) wood: i.e. different celltypes or parts of the tree are different "reservoirs" of Sr with different isotopic compositions. Hence, different leachates represent different reservoirs and the final composition of the "cleaned" waterlogged wood might correspond to the original composition of the fresh alphacellulose. Another explanation would be external contamination. Since none of the reagents contain Sr this seems unlikely (all were tested and the results were close to blanks).

In Fig. 6 and Table 6 the proportion of Sr removed at each step of the cleaning is shown. This is determined using the sum of Sr extracted at each individual step normalised to the original mass of dry wood. It illustrates that the archaeological wood contains more Sr than the experimentally waterlogged wood. This is probably due to the fact that archaeological timbers from shipwrecks spent more time in contact with seawater. The other difference is found in the way waterlogging was achieved; in our case, a piece of wood was submerged in water in a closed container. At some point the wood and surrounding water will be in equilibrium and no more $\mathrm{Sr}$ will be taken up. Whereas in the case of shipwrecks there is a constant movement of water with fresh Sr being supplied. It should also be noted that there is a distinct possibility that waterlogged archaeological wood does not in fact contain any of the original $\mathrm{Sr}$ anymore, as the endogeneous $\mathrm{Sr}$ was exchanged with the surrounding water while the archaeological wood was submerged.

From Fig. 6 and Table 6, it is apparent that HF is the most efficient at removing $\mathrm{Sr}$, and the MQ wash after the HF wash also solubilizes more $\mathrm{Sr}$ than the first MQ extraction. The Sr in the HF and MQ leachates is slightly more radiogenic than seawater, though much closer to the seawater signature than the original wood signature (Fig. 5). The second thing to notice is that the normalised concentrations in different experiments are not consistent with each other (Table 6). This might be linked to different parts of the wood being more affected by exogenous $\mathrm{Sr}$ (by virtue of being closer to the surface and/or having more free space for $\mathrm{Sr}$ to be deposited). What this certainly means, is that monitoring how much $\mathrm{Sr}$ is removed cannot be used on its own to determine complete removal of all exogenous $\mathrm{Sr}$.

The law of conservation of mass dictates that if there is $\mathrm{x} \mathrm{ng}$ of $\mathrm{Sr}$ in the wood, and $\mathrm{y} n$ is added from water, the final isotopic composition of the wood would be a weighted average of both signatures. This is expressed in equation 1 with ${ }^{87} \mathrm{Sr} /{ }^{86} \mathrm{Sr}_{\text {wood }}$ and ${ }^{87} \mathrm{Sr} /{ }^{86} \mathrm{Sr}_{\text {water }}$ the isotopic composition of the original wood and water respectively.

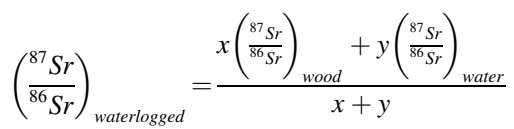

Similarly, a mass balance can be produced for the leaching experiments, where $c_{x}$ is the concentration in part $\mathrm{x}$ : 

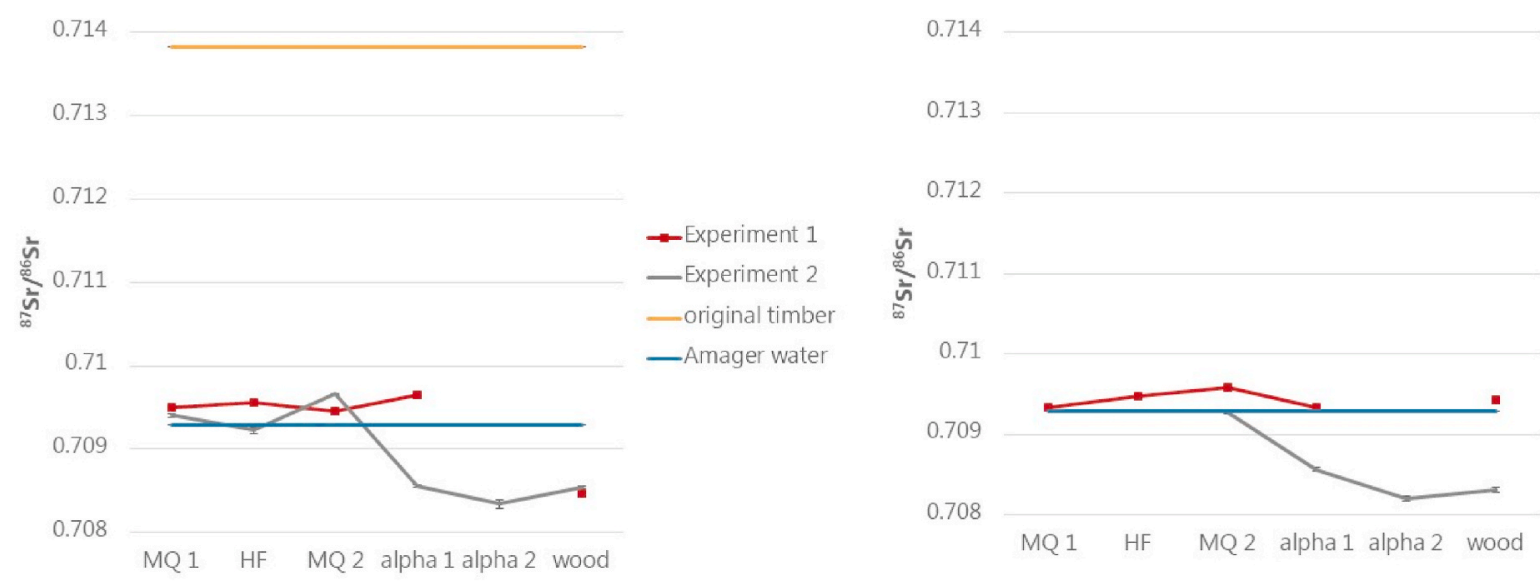

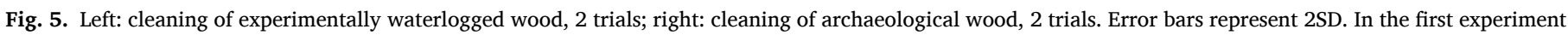
all the leachates of the alpha-cellulose extraction were analysed together, in the second experiment it was split in two.

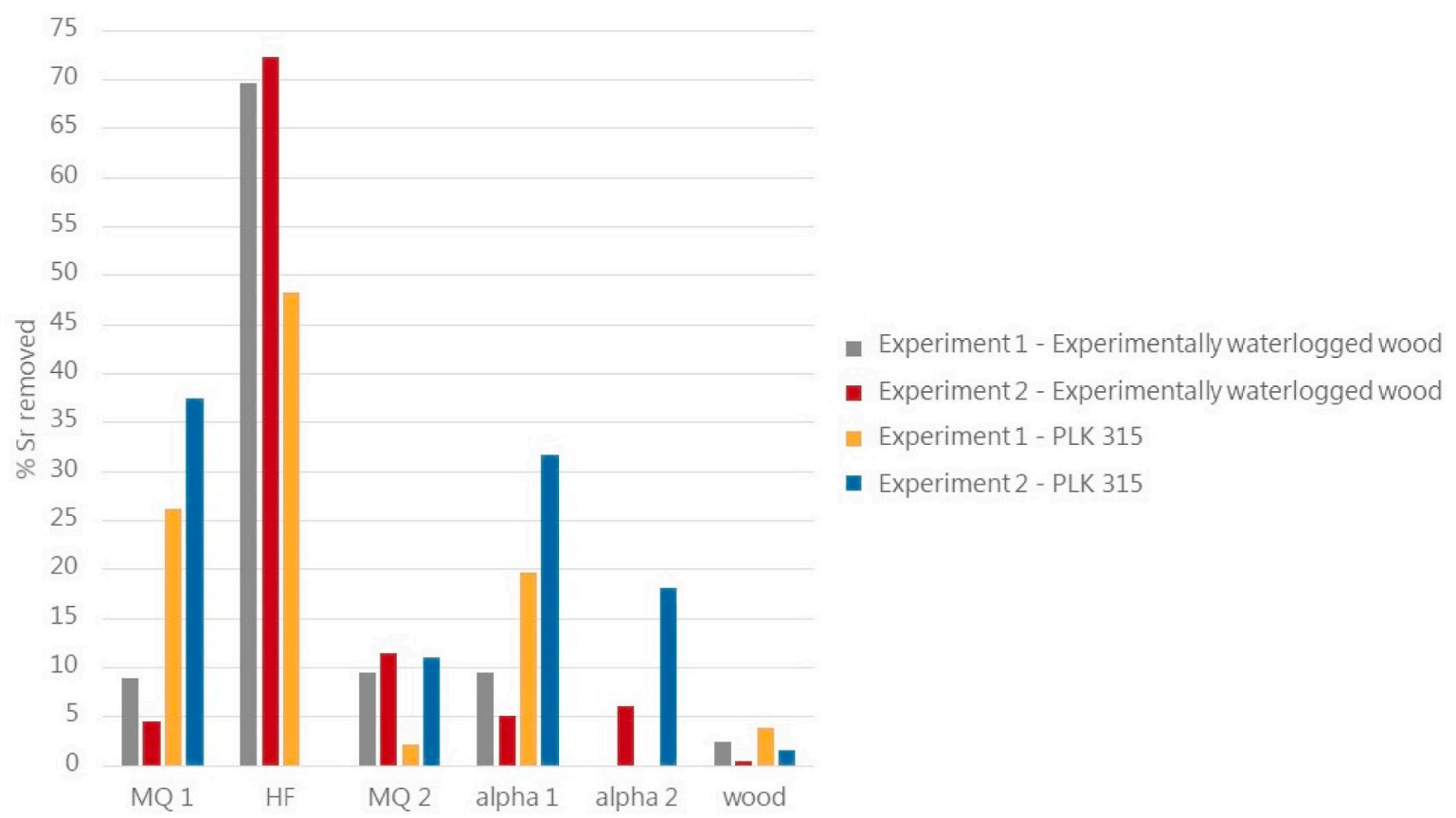

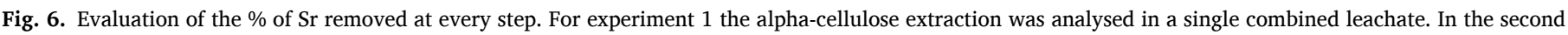
PLK 315 experiment the HF leachate is missing, as such the results are not entirely correct, i.e. the sum of the extracted Sr is below $100 \%$.

$\left(\frac{{ }^{87} S r}{{ }^{86} S r}\right)_{\text {waterlogged }}=\frac{c_{M Q 1}\left(\frac{87 S r}{{ }^{86} S r}\right)_{M Q 1}+c_{H F}\left(\frac{87 S r}{{ }^{86} S r}\right)_{H F}+c_{M Q 2}\left(\frac{{ }^{87} S r}{{ }^{86} S r}\right)_{M Q 2}+c_{\text {alpha }}\left(\frac{{ }^{87} S r}{{ }^{86} S r}\right)_{\text {alpha }}+c_{\text {wood }}\left(\frac{{ }^{87} S r}{{ }^{86} S r}\right)_{\text {wood }}}{c_{M Q 1}+c_{H F}+c_{M Q 2}+c_{\text {alpha }}+c_{\text {wood }}}$

Based on this balance, the Sr isotopic composition of the experimentally waterlogged wood should be $0.70953 \pm 0.00002$ (experiment 1) or $0.70920 \pm 0.00887$ (experiment 2). The direct measurement of the waterlogged wood yielded $0.70959 \pm 0.00002$. The error in experiment 2 arises from the error propagation with the HF leach associated with the highest uncertainty and the highest concentration (Table 4). Based on the mass balance of experiment 1 , approximately $92.4 \%$ of the $\mathrm{Sr}$ is exogeneous. Based on the large error associated with experiment 2, there is little point in performing the same analysis.

When comparing the absolute amount of Sr present in the archaeological and experimentally waterlogged wood, it can be observed that the archaeological wood contains more Sr, which is probably exogeneous. Von Holstein et al. (2015) also observed that archaeological wool had in general higher Sr concentrations, though the range of concentrations was larger than for experimentally buried wool. 


\section{Conclusion}

Three different cleaning methods were assessed to remove exogenous $\mathrm{Sr}$ from experimentally waterlogged and archaeological wood. It was shown that HF is most efficient at removing $\mathrm{Sr}$, but that none of the methods applied yielded satisfactory results to identify the prewaterlogged isotopic composition. Furthermore, a high variability in quantity of extracted Sr and isotopic composition of leachates was noted which makes any predictions on how to best clean the material difficult. Archaeological wood contains more exogenous Sr than experimentally waterlogged wood, this is attributed to both the longer submersion time and the constant supply of fresh $\mathrm{Sr}$ in the case of archaeological wood. Furthermore, as the cellular structure of the archaeological wood gradually breaks down, some or all of the endogeneous Sr might be leached during waterlogging.

In the MQ-HF experiment it was shown that during the leaching, both exogenous and original $\mathrm{Sr}$ are removed, meaning that overcleaning could have an adverse effect in partially or even completely removing the Sr of interest.

Finally, the ashing experiments showed that, due to the small sample size, the measurement uncertainties were higher. Therefore, we do not recommend ashing of small samples.

\section{Declaration of competing interest}

There are no conflicts of interest to report for any of the authors.

\section{Acknowledgements}

This research was carried out within the project Northern Europe's timber resource - chronology, origin and exploitation (TIMBER), which received funding from the European Research Council (ERC) under the European Union's Horizon 2020 research and innovation program (Grant agreement No. 677152). The authors want to thank Søren Nielsen from the Viking Ship Museum for the modern oak sample, Jens Auer for the archaeological sample, Toby Leeper for help with the TIMS, Toni Larsen and Cristina Nora for advice on procedures and Robert Frei for useful discussions.

\section{Appendix A. Supplementary data}

Supplementary data to this article can be found online at https://doi. org/10.1016/j.jas.2020.105261.

\section{References}

Andreu-Hayles, L., Levesque, M., Martin-Benito, D., Huang, W., Harris, R., Oelkers, R., et al., 2019. A high yield cellulose extraction system for small whole wood samples and dual measurement of carbon and oxygen stable isotopes. Chem. Geol. 504, 53-65 https://doi.org.10.1016/j.chemgeo.2018.09.007.

Barnett-Johnson, R., Pearson, T.E., Ramos, F.C., Grimes, C.B., MacFarlane, R.B., 2008. Tracking natal origins of salmon using isotopes, otoliths, and landscape geology. Limnol. Oceanogr. 53, 1633-1642 https://doi.org.10.2307/40058282.

Beard, B.L., Johnson, C.M., 2000. Strontium isotope composition of skeletal material can determine the birth place and geographic mobility of humans and animals. J. Forensic Sci. 45, 1049-1061.

Bird, M.I., Levchenko, V., Ascough, P.L., Meredith, W., Wurster, C.M., Williams, A., et al. 2014. The efficiency of charcoal decontamination for radiocarbon dating by three pre-treatments - ABOX, ABA and hypy. Quat. Geochronol. 22, 25-32.

Blank, M., Sjogren, K.-., Knipper, C., Frei, K.M., Stora, J., 2018. Isotope values of the bioavailable strontium in inland southwestern Sweden-A baseline for mobility studies. PloS One 13. https://doi.org/10.1371/journal.pone.0204649.

Blum, J.D., Hamburg, S.P., Yanai, R.D., Artur, M.A., 2012. Determination of foliar $\mathrm{Ca} / \mathrm{Sr}$ discrimination factors for six tree species and implications for Ca sources in northern hardwood forests. Plant Soil 356, 303-314. https://doi.org/10.1007/s11104-011 $1122-2$.

Brems, D., Ganio, M., Latruwe, K., Balcaen, L., Carremans, M., Gimeno, D., et al., 2013. Isotopes on the beach, part 1: strontium isotope ratios as a provenance indicator for lime raw materials used in Roman Glass-making. Archaeometry 50, 214-234. https://doi.org/10.1111/j.1475-4754.2012.00702.x.

Bridge, M., 2012. Locating the origins of wood resources: a review of dendroprovenancing. J. Archaeol. Sci. 39, 2828-2834.
Brinkkemper, O., Braadbaart, F., van Os, B., van Hoesel, A., van Brussel, A.A.N., Fernandes, R., 2018. Effectiveness of different pre-treatments in recovering preburial isotopic ratios of charred plants. Rapid Commun. Mass Spectrom. 32, 251-261.

Büntgen, U., Kolár, T., Rybnícek, M., Koňasová, E., Trnka, M., Alexander, A.č., et al. 2020. No age trends in oak stable isotopes. Paleoceanography and Paleoclimatology 35.

Charlier, B.L.A., Ginibre, C., Morgan, D., Nowell, G.M., Pearson, D.G., Davidson, J.P., et al., 2006. Methods for the microsampling and high-precision analysis of strontium and rubidium isotopes at single crystal scale for petrological and geochronological applications. Chem. Geol. 232, 114-133. https://doi.org/10.1016/j. chemgeo.2006.02.015.

Connolly, J.H., Shortle, W.C., Jellison, J., 1999. Translocation and incorporation of strontium carbonate derived into calcium oxalate crystals by the wood decay fungus Resinicium bicolor. Can. J. Bot. 77, 179-187.

Dalicsek, D., Diez Merida, D., Steffensen, F., 2018. Evaluation of anomalies in temporary exclusion zones M_R39_07049 and M_R40_10085. Archaeological Diving Investigation. Ref.3544-5533.01. Schwerin, Landesamt für Kultur und Denkmalpflege.

Daly, A., 2007. Timber, Trade and Tree-Rings. A Dendrochronological Analysis of Structural Oak Timber in Northern Europe, C. AD 1000 to C. AD 1650. Ph.D. Thesis Submitted February 2007. University of Southern Denmark.

Daly, A., 2019. Dendrochronological Analysis of Timbers from a Shipwreck Found at Peenemündung, Germany - Ostsee VII, Fpl 105. dendro.Dk Report 2019:42 (Copenhagen).

Daly, A., Nymoen, P., 2008. The Bøle Ship, Skien, Norway - research history, dendrochronology and provenance. Int. J. Naut. Archaeol. 37 (1), 153-170. https:// doi.org/10.1111/j.1095-9270.2007.00157.x.

De Bonis, A., Arienzo, I., D’Antonio, M., Franciosi, L., Germinario, C., Grifa, C., et al., 2018. Sr-Nd isotopic fingerprinting as a tool for ceramic provenance: its application on raw materials, ceramic replicas and ancient pottery. J. Archaeol. Sci. 94, 51-59. https://doi.org/10.1016/j.jas.2018.04.002.

Drouet, T., Herbauts, J., Demaiffe, D., 2005. Long-term records of strontium isotopic composition in tree rings suggest changes in forest calcium sources in the early 20th century. Global Change Biol. 11, 1926-1940. https://doi.org/10.1111/j.1365 2486.2005.01034.x.

Durand, S.R., Shelley, P.H., Antweiler, R.C., Taylor, H.E., 1999. Trees, chemistry, and prehistory in the American Southwest. J. Archaeol. Sci. 26, 185-203. https://doi. org/10.1006/jasc.1998.0315.

Frei, K.M., Frei, R., Mannering, U., Gleba, M., Nosch, M.L., Lyngstrøm, H., 2009. Provenance of ancient textiles - a pilot study evaluating the strontium isotope system in wool. Archaeometry 51, 252-276. https://doi.org/10.1111/j.1475 4754.2008.00396.x.

Frei, K.M., Bergerbrant, S., Sjögren, K.-., Jørkov, M.L., Lynnerup, N., Harvig, L., et al., 2019. Mapping human mobility during the third and second millennia BC in presentday Denmark. PloS One 14. https://doi.org/10.1371/journal.pone.0219850.

Frei, R., Frei, K.M., Jessen, S., 2020. Shallow retardation of the strontium isotope signal of agricultural liming - implications for isoscapes used in provenance studies. Sci. Total Environ. 706 https://doi.org/10.1016/j.scitotenv.2019.135710.

Hajj, F., Poszwa, A., Bouchez, J., Guérold, F., 2018. Radiogenic and "stable" strontium isotopes in provenance studies: a review and first results on archaeological wood from shipwrecks. https://doi.org/10.1016/j.jas.2017.09.005, 86, 24-49.

Hartman, G., Richards, M., 2014. Mapping and defining sources of variability in bioavailable strontium isotope ratios in the Eastern Mediterranean. Geochem. Cosmochim. Acta 126, 250-264. https://doi.org/10.1016/j.gca.2013.11.015.

Hoogewerff, J.A., Reimann, C., Ueckermann, H., Frei, R., Frei, K.M., van Aswegen, T., Stirling, C., Reid, M., Clayton, A., Ladenberg, A., et al., 2019. Bioavailable ${ }^{87} \mathrm{Sr} /{ }^{86} \mathrm{Sr}$ in European soils: a baseline for provenancing studies. Sci. Total Environ. 672, 1033-1044. https://doi.org/10.1016/j.scitotenv.2019.03.387.

Horstwood, M.S.A., Evans, J.A., Montgomery, J., 2008. Determination of Sr isotopes in calcium phosphates using laser ablation inductively coupled plasma mass spectrometry and their application to archaeological tooth enamel. Geochem. Cosmochim. Acta 72, 5659-5674. https://doi.org/10.1016/j.gca.2008.08.016.

Ladegaard-Pedersen, P., Achilleos, M., Dörflinger, G., Frei, R., Kristiansen, K., Frei, K.M., 2020. A strontium isotope baseline of Cyprus. Assessing the use of soil leachates, plants, groundwater and surface water as proxies for the local range of bioavailable strontium isotope composition. Sci. Total Environ. 708 https://doi.org/10.1016/j. scitotenv. 2019.134714.

Lorentzen, B., Manning, S.W., Cvikel, D., Kahanov, Y., 2014. High-precision dating the Akko 1 shipwreck, Israel: wiggle-matching the life and death of a ship into the historical record. J. Archaeol. Sci. 41, 772-783. https://doi.org/10.1016/j. jas.2013.10.013.

Maurer, A., Galer, S.J.G., Knipper, C., Beierlein, L., Nunn, E.V., Peters, D., et al., 2012. Bioavailable ${ }^{87} \mathrm{Sr} /{ }^{86} \mathrm{Sr}$ in different environmental samples - effects of anthropogenic contamination and implications for isoscapes in past migration studies. Sci. Total Environ. 433, 216-229. https://doi.org/10.1016/j. scitotenv.2012.06.046.

Million, S., Eisenhauer, A., Billamboz, A., Rösch, M., Krausse, D., Nelle, O., 2018. Iron Age utilization of silver fir (Abies alba) wood around the Heuneburg - local origin or timber import? Quat. Int. 463, 363-375. https://doi.org/10.1016/j. quaint.2017.05.035.

Ostapkowicz, J., Schulting, R.J., Wheeler, R., Newsom, L., Brock, F., Bull, I., et al., 2017. East-central Florida pre-Columbian wood sculpture: radiocarbon dating, wood identification and strontium isotope studies. J. Archaeol. Sci.: Report 13, 595-608.

Palmer, M.R., Edmond, J.M., 1989. The strontium isotope budget of the modern ocean. Earth Planet Sci. Lett. 92, 11-26. https://doi.org/10.1016/0012-821X(89)90017-4. 
Rich, S., Manning, S.W., Degryse, P., Vanhaecke, F., Van Lerberghe, K., 2012. Strontium isotopic and tree-ring signatures of Cedrus brevifolia in Cyprus. J. of Anal. At. Spectrom. 27, 796-806. https://doi.org/10.1039/C2JA10345A.

Rich, S., Manning, S.W., Degryse, P., Vanhaecke, F., Latruwe, K., Van Lerberghe, K., 2016a. To put a cedar ship in a bottle: dendroprovenancing three ancient East Mediterranean watercraft with the ${ }^{87} \mathrm{Sr} /{ }^{86} \mathrm{Sr}$ isotope ratio. J. Archaeol. Sci.: For. Rep. 9, 514-521. https://doi.org/10.1016/j.jasrep.2016.08.034.

Rich, S., Manning, S.W., Degryse, P., Vanhaecke, F., Van Lerberghe, K., 2016b. Provenancing East Mediterranean cedar wood with the ${ }^{87} \mathrm{Sr} /{ }^{86} \mathrm{Sr}$ strontium isotope ratio. Archaeol. and Anthropol. Sci. 8, 467-476 https://doi.org/10.1007/s12520015-0242-7.

Serdar, B., Demiray, H., 2012. Calcium oxalate crystal types in three oak species (Quercus L.) in Turkey. Turk. J. Biol. 36, 386-393. https://doi.org/10.3906/biy1109-35.

Wilmes, M., Bataille, C.P., James, H.F., Moffat, I., McMorrow, L., Kinsley, L., et al., 2018. Mapping of bioavailable strontium isotope ratios in France for archaeological provenance studies. Appl. Geochem. 90, 75-86. https://doi.org/10.1016/j. apgeochem.2017.12.025.

Snoeck, C., Schulting, R.J., Brock, F., Rodler, A.S., Van Ham-Meert, A., Mattielli, N., Ostapkowicz, J. submitted, Testing Various Pre-treatments on Artificially Waterlogged and Pitch-Contaminated Wood for Strontium Isotope Analyses, Frontiers in Ecology and Evolution, Section Paleoecology.

Snoeck, C., Ryan, S., Pouncett, J., Pellegrini, M., Claeys, P., Wainwright, A.N., et al., 2020. Towards a biologically available strontium isotope baseline for Ireland. Sci. Total Environ. 712 https://doi.org/10.1016/j.scitotenv.2019.136248.

St George, S., Outridge, P.M., Nielsen, E., 2006. High-resolution dendrochemical analysis of flood-affected oaks using laser ablation ICP-mass spectrometry. IAWA J. 27, 19-31. https://doi.org/10.1163/22941932-90000134.
Steelandt, S., Pierson-Wickmann, A.-., Bhiry, N., Marguerie, D., Coz, M.B.-., 2016. Chemical differentiation between immersed and dry wood samples in nunavik (northern quebec, Canada): preliminary results. Arctic Antarct. Alpine Res. 48, 315-325. https://doi.org/10.1657/AAAR0014-082.

Steffensen, F., 2019. Das Peenemündung 105 Wrack - ein spätmittelalterlicher Schiffsfund aus dem Greifswalder Bodden. Master Thesis. Kiel, Christian-AlbrechtsUniversität zu Kiel. Philosophische Fakultät.

Thomsen, E., Andreasen, R., 2019. Agricultural lime disturbs natural strontium isotope variations: implications for provenance and migration studies. Sci. Advances 5 https://doi.org/10.1126/sciadv.aav8083.

Toxvaerd, S., 2020. The strontium isotope ratio ${ }^{87} \mathrm{Sr} /{ }^{86} \mathrm{Sr}$ in archaeological organic matter conserved in acidic anaerobic environments is hard to interpret. J. Archaeol. Sci.: Report 31, 102379.

Traoré, M., Kaal, J., Martínez Cortizas, A., 2018. Chemometric tools for identification of wood from different oak species and their potential for provenancing of Iberian shipwrecks (16th-18th centuries AD). J. Archaeol. Sci. 100, 62-73. https://doi.org/ 10.1016/j.jas.2018.09.008.

Von Holstein, I.C.C., Font, L., Peacock, E.E., Collins, M.J., Davies, G.R., 2015. An assessment of procedures to remove exogenous $\mathrm{Sr}$ before ${ }^{87} \mathrm{Sr} /{ }^{86} \mathrm{Sr}$ analysis of wet archaeological wool textiles. J. Archaeol. Sci. 53, 84-93 https://doi.org/10.1016/j. jas.2014.10.006.

Waight, T.E., Tørnqvist, J.B., 2018. Sr isotope zoning in plagioclase from andesites at Cabo De Gata, Spain: evidence for shallow and deep contamination. Lithos 308-309, 159-167. https://doi.org/10.1016/j.lithos.2018.03.007.

Weis, D., Kieffer, B., Maerschalk, C., Barling, J., de Jong, J., Williams, G., Hanano, D., Pretorius, W., Mattielli, N., Scoates, J.S., Goolaerts, A., Friedman, R.M., Mahoney, J. B., 2006. High-precision isotopic characterization of USGS reference materials by TIMS and MC-ICP-MS. G-cubed 7 (8), 1-30. https://doi.org/10.1029/ 2006 GC001283. 